\title{
Changes in Worship Rituals of the Ede People in Buon Ma Thuot - Viet Nam Highland Today
}

\author{
PhD student Mai Trong An Vinh \\ Hanoi National University of Education, Viet Nam
}

\begin{abstract}
:
Considered as "local residents" in Buon Ma Thuot, the Ede people have a long history and culture in this land. In the process of community development, Ede people also have had a cultural exchange intertwined with the Kinh people and other ethnic groups (Tay, Nung, Gia Rai people...), creating a unique cultural interference between the Ede people and other ethnic groups in the region that makes Ede people's culture increasingly diverse and rich. This process of contact and cultural exchange has made the socio-economic development of the Ede people in Buon Ma Thuot happen more and more quickly; besides, there is a significant impact on the Ede people's cultural identity. This article focuses on the changes of the Ede people's worship rituals in Buon Ma Thuot in the context of international economic integration today.
\end{abstract}

Keywords: Ritual; Ede; Tradition; Changes.

DOI: $10.7176 /$ RHSS/9-24-07

Publication date: December $31^{\text {st }} 2019$

\section{Preface}

Vietnamese cultural identity is a system of values created by the 54 ethnic groups in its process of labor and creation. In order to preserve and promote the traditional strength of cultural values in the process of stepping up industrialization and modernization in Vietnam today, it is indispensable to build and develop an advanced Vietnamese culture imbued with national identity.

Buon Ma Thuot is located in the center of the Central Highlands region of Vietnam, the Ede people have a long history of culture in this land. In the current period, the globalization has made the Ede cultural life more and more diverse and rich. Because of polethistic worship, the Ede people's life forms a very diverse and unique system of worship rituals; these rituals express the Ede people's profound human philosophy of people, life and death. The globalization has made the Ede people's worship rituals increasingly clear due to the process of cultural interaction and exchange with other ethnic groups. The inevitable consequence is that the Ede people's cultural identity is gradually fading compared to the past. Therefore, the research to objectively view from a scientific perspective to identify the change in the worshiping ceremony of the Ede people in Buon Ma Thuot is necessary to contribute a small amount of effort in making more appropriate policies for the preservation and promotion of cultural values of the Ede people in the era of globalization taking place in Vietnam is getting stronger.

\section{Contents}

\subsection{Worship ritual concept \\ * Ritual}

The Vietnamese Dictionary of the Dictionary of Vietnamese Dictionary points out the concept of a ritual as the etiquette and procedure of a ceremony ${ }^{1}$. And the General Anthropology curriculum of the University of Social Sciences and Humanities in Ho Chi Minh City states that a ritual in a certain extent as well as customs and practices, is the conventions that is repeated into habits, deeply ingrained into religious consciousness and socialcultural life ${ }^{2}$.

The ritual is formed together with human society, in which man is the subject of society. The ritual is often performed in the spiritual life of each ethnic group. Almost all ethnic groups in the world have rituals of varying degrees. The ritual is a common word, meant to express the established communication patterns of one or more people for one or more others and for one or more gods, the supernatural being. The ritual consists of many combined rites. Nghi means majesty, appearance, modesty and exemplary. The rite is the implementation of the rules, the pattern that the ancients had done; is a form of social organization. Thus, the Ritual is understood as the rites when performing the ceremony, converging all the elements of spiritual culture.

The anthropologist E.B.Tylor in his original work of Culture said that the ritual is a means of communication with soul entities ${ }^{3}$ and it is best to put faith in spiritual entities as a minimum definition of religion ${ }^{4}$. And A.A Radugin in Dictionary of Polytechnic Culture said about the ritual as follows: the ritual appears in theology to

\footnotetext{
${ }^{1}$ Quoted from the Center of Dictionary (2007), Vietnamese Dictionary, Danang Publisher, Da Nang, Page 355.

${ }^{2}$ Quoted from Ho Chi Minh City University of Social Sciences and Humanities (2008), General Anthropology Curriculum, Ho Chi Minh City National University Publishing House, Page 24.

${ }^{3}$ Quoted from E.B.Tylor (2001), Primitive Culture, National Culture Publishing House, Hanoi, Page 946.

${ }^{4}$ Quoted from E.B.Tylor (2001), Primitive Culture, National Culture Publishing House, Hanoi, Page 947.
} 
demonstrate the effective relationship between everyday life and the supernatural. The ritual is passed down not only in religion but also in life ${ }^{l}$.

According to the needs of the spiritual life, in response to both fear and desire of the divine gift, humans have formed a belief system and a ritual system. The ritual is passed down not only in religion but also in daily life, especially in traditional folklore. Cultural researchers have divided many different types of rituals: Agricultural ritual; Fishery ritual; Ritual of life cycle; Ritual of worshiping progenitor; Ritual of worshiping ancestors,...

The ritual plays an important role in the cultural identity of a clan and a people. The ritual is the overall picture of conduct, psychological identity and ethical norms of a clan and a people. Of course, in the process of campaigning according to the history's flow, due to the objective and subjective effects, sacredness, form, content of the ritual of each clan, each ethnic group have certain changes because cultural identity is not immutable but cultural identity is what was created through each historical period.

\section{* Worship}

Vietnamese dictionary of Nguyen Ton Nhan \& Phu Van Han says that worship is worshiping with rituals and worshiping $^{2}$. As for the Vietnamese dictionary of the Institute of Linguistics, edited by Hoan Phe, it is said that worshiping is to pay homage to a god, a sacred object or the soul of a dead person in the form of rituals or worship according to customs or beliefs $s^{3}$ and offering is offering offerings to the dead or spirits of a dead person, according to beliefs or traditional customs ${ }^{4}$.

The worship is a form of ritual that expresses people's beliefs in the spirit world. This is a form of expressing the most universal belief. The form of worship has occurred since the appearance of human society. Worship is a traditional ethic of every individual and nation. The worship is the highest form of rituals manifested to the divine world, which is also a good teaching, the foundation for human morality in life. Worshiping means showing respect to our ancestors, ancestors, and saints who have contributed to the country and the gods for whom we have faithfully sent. Offering is also understood in the sense of offering sacrifices, offering gifts to the ancestors, ancestors, ancestors, and saints with meritorious services to the country... whom we always respect and pray for their witness to our sincerity. Within the scope of this article, the author uses the word cozy in the sense of offering.

From the above analysis, we can understand that the worship rituals is rituals and order of steps for conducting a ceremony for the predecessors, ancestors, sages and saints of the country and the gods, whom we always respect and pray for their witness to our sincerity.

\subsection{The Ede people in Buon Ma Thuot}

Buon Ma Thuot is the name of a "village" of Ede Kpa people. At the end of the nineteenth century, there was only one village with about 50 long houses managed by the sheik Ama Thuot. By the early years of the twentieth century, Buon Ma Thuot was no longer a single trade but gathered and developed dozens of other villages. However, Buon Ma Thuot is still a big village of the whole region and it is also governed by the sheik Ama Thuot ${ }^{5}$. Currently Buon Ma Thuot is a city under Dak Lak province, there are about 42 ethnic groups living, among the indigenous and Ede ethnic groups with the largest population ${ }^{6}$.

The Ede people is derived from the Malay speaking ethnic group in the Pacific Islands. Currently, the Ede people still have matriarchy. The Ede people include the following main groups: Ede Kpa, residing mainly in Buon Ma Thuot and scattered in districts of Krong Ana, Krong Pak, Cu Mgar, ... Dak Lak province; Edham Adham, residing mainly in districts Krong Buk, Cu Mgar, Krong Nang, ... of Dak Lak province; Ede Mdhur, mainly residing in the district of Mrak in the eastern part of Dak Lak province; Ed Bih, mainly residing in Krong Ana and Krong Kno districts of Dak Nong province; Ede Krung, residing mainly in the districts of Ea Hleo, Krong Buk of Dak Lak province ... In daily life, the Ede people follow matriarchy, so children bring mother's family. The wife will marry a husband for her and the man after marriage will live with his wife's family. The Ede people 's livelihood in Buon Ma Thuot used to be mainly cultivated but today, they also process agricultural products, grow industrial crops such as coffee, rubber, pepper, cocoa... The main livelihood of the Ede people in Buon Ma Thuot is mainly agriculture. The worship system of the Ede people is very diverse and rich, however within the scope of this paper, the author focuses on the life cycle and agricultural rituals of this ethnic group, as these are the two most important rituals in the life of the Ede people.

\footnotetext{
${ }^{1}$ Quoted from A.A. Radugin (translator Vu Dinh Phong, 2002), Dictionary of Cultural Science, Institute of Literature and Art, Hanoi, pp.326 ${ }^{2}$ Quoted from Nguyen Ton Nhan \& Phu Van Han (co-editor, 2013), Vietnamese dictionary, Southern Institute of Social Sciences, Polytechnic Dictionary Publishing House, Hanoi, Page 1049.

${ }^{3}$ Quoted from Hoan Phe (chief editor, 2012), Vietnamese Dictionary, Institute of Linguistics, Polytechnic Dictionary Publishing House, Hanoi, Page 1222.

${ }^{4}$ Quoted from Hoan Phe (chief editor, 2012), Vietnamese Dictionary, Institute of Linguistics, Polytechnic Dictionary Publishing House, Hanoi, Page 298 .

${ }^{5}$ In Ede, Ama means father, Y Thuot refers to a son named Thuot - Buon Ma Thuot is an abbreviation: Y Thuot father's village.

${ }^{6}$ Quoted from Provincial Party Committee - People's Council - People's Committee of Dak Lak Province (2015), Geography of Dak Lak Province, Social Sciences Publishing House, Hanoi.
} 


\section{Outline of life cycle ritual and agricultural ritual of the Ede people in Buon Ma Thuot 3.1. Outline of life cycle ritual}

For the Ede people, the life-cycle ritual plays an important role in their lives because it is associated with every transition in each individual's life and greatly affects each member of the family. The Ede people believe in the sacredness of the gods, where rituals provide a bridge for humans to access the gods. The life cycle ritual is usually divided into three main stages: birth, maturity and death.

* The stage of birth, including rituals: ritual for the mother and fetus's health, ritual for fetus protection, ritual for the mother after giving birth, ritual for midwive's health, ritual for the mother's health, ritual for blowing ears, ritual for naming child.

* The stage of maturity, including rituals: ritual for children's maturity, ritual for wearing necklace, ritual for teeth flossing, ritual for offer, ritual for wedding.

* The stage of death, including rituals: ritual for dead, ritual for the dead by accident, ritual for buring the dead, ritual for bỏ mả.

\subsection{Outline of agricultural ritual}

The Ede people have a way of dividing the time in agricultural production based on the cycle of twelve bright moons and one bright moon corresponding to one month as per year. The first bright moon they usually spend time to play and rest mainly; on the second bright moon, they often spend time in the forest to hunt and hunt for wild animals as a food reserve for the rainy season; the third bright moon officially started the Ede people's agricultural cycle, they started clearing the fields and reclaiming the moon this morning to prepare for the new crop to begin; just like that, on the fourth bright moon, Ede people spend time to clear fields, clear the fields and clear the fields to prepare for sowing and planting rice; on the fifth bright moon, they often organize a ritual to pray for rain and an worship for the first rain; on the sixth bright moon, the Ede people often sow their rice and plant crops; On the seventh bright moon, the Ede people often spend this time weeding on milpas; on the eighth bright moon, the Ede people often cultivate and pray for the gods to protect the cultivation; the nineth bright moon is an occasion for the Ede people to hold a new rice-worshiping; on the tenth bright moon, they wait to harvest rice and other crops; on the eleventh bright moon, the whole village comes together to harvest crops and pluck rice, this moon was also an opportunity for them to hold a ritual to thank the ancestors and the gods and on the last full moon in a year, when the harvest of crops and plucking of rice is completed, this is the opportunity for Ede people to hold the ritual for importing rice into bamboo basket ${ }^{l}$. At each stage of shifting cultivation, at different times, the Ede people will conduct the corresponding rituals in order to pray to the gods to bless their cultivation with good rain and good weather. The Ede's agricultural rituals include the following main rites: ritual for the sylph; ritual for grassing; ritual for rice sowing; ritual for rice seed; ritual for paying for rain; ritual for the first rain; ritual for rice watering and New rice eating ceremony.

\section{Changes in worshiping rituals of the Ede people in Buon Ma Thuot today}

The main cause of the change in the worshiping rituals of the Ede people in Buon Ma Thuot today is due to the contact and cultural exchange, besides, there are some other reasons such as the policies of socio-economic development of the state, the development of the production force with the application of science and technology into daily life has been increasing and the people's intellectual standard has been improved. The change takes place in many different aspects of the worship rituals but within the scope of this article, the author only mentions the change of the two most important aspects: the change in holiness and the change in content, form of worship rituals.

\subsection{The change in holiness}

\section{* Rutual for life circle}

In the current period, with the development of an increasingly modern health system, when the Ede women get pregnant, they often go to the hospital for regular prenatal check-ups, not to pray to the gods as previously, therefore, the implementation of the worshiping to protect the fetus is less and less done in theo Ede people's families. During the pregnancy, if the Ede woman is ill, the family often takes her to the local hospitals for medical examination, they no longer perform the ritual for the mother and fetus's health as previously. So the holiness in the life cycle ritual also decreases compared to before. Now, when the Ede women give birth, they no longer invite midwives to give birth at home, they will take her to the hospital to ensure the health of the mother and the newborn baby. The belief of the Ede people today in the health system is increasing, leading to a decrease in the belief in the gods in protecting the health of their people, because of that, the ritual for midwives' health in the Ede families in Buon Ma Thuot has gradually disappeared. The time for performing the life cycle ritual is shortened compared to the previous tradition, so that also reduces the holiness of the ritual. The ritual for tooth brushing is no longer

\footnotetext{
${ }^{1}$ Rice basket is woven from bamboo and neohouzeaua, with high walls, wide and round mouth, often with a lid.
} 
present in the Ede families in Buon Ma Thuot.

The wharf in each Ede village is considered as the convergence of vitality of the whole village and as a place of spiritual beliefs passed down for generations but now the wharf is disappearing in the Ede villages in Buon Ma Thuot, so in the process of performing the life cycle ritual, they have to omit the rituals related to the wharf. This situation has greatly reduced the holiness of the life cycle ritual.

The initiative of the Ede girls in Buon Ma Thuot in the ritual for offer has decreased significantly in the current period. The ritual for demand for broom-price is now almost an agreement in advance according to the ability of the girl's family, but it is no longer a heavy problem of "challenging" the offering as traditionally of the traditional Ede people. Nowadays, the girl's family no longer brings gifts to make the family's meal as traditional customs, most of the gifts are converted into cash and given to the boy's family before the wedding takes place, the gifts that the girl's family brings to the boy's family during the wedding ceremony are mostly symbolic. The issue of organizing wedding ceremonies is mainly employed by the Ede people from wedding services from outside the village and brought until the wedding takes place. These factors have made the role of life-cycle ritual in the life of the Ede people in Buon Ma Thuot more and more, thus leading to a decrease in the holiness of lifecycle ritual as a necessary.

The Ede villages in Buon Ma Thuot now no longer owns separate cemeteries as before so when a family member in Ede family dies, he/she has to be buried in cemeteries regulated by the government, the ritual for burying the dead and ritual for bo mả have been omitted a number of rituals to suit the current specific circumstances. The architecture of the Ede's tombs has also changed a lot, it is no longer following the traditional Ede-style architecture, thus reducing the holiness in the ritual of life cycle. In the ritual for burying the dead of the former traditional Ede people, when the coffin was brought to the graveyard of the Ede village, the family would drop a hen and some rice or rice with the idea that it was the property for the dead when returning to the afterlife. After lowering the coffin to the acupuncture point, before covering the earth, the Ede people took a jug of wine with perforated wine placed at the head of the acupuncture point and a bamboo tree was carved through all the inner bamboo eyes and then placed from the bottom out of the mouth of the vent above the head of the coffin in order that every day the family of the dead would bring rice, food, wine ... into the bamboo tube to slip into the grave with the notion of "raising" the dead. But now, these rituals are almost no longer performed in many Ede families in Buon Ma Thuot, so the holiness in the life-cycle ritual is also greatly reduced.

\section{* Agricultural ritual}

The Ede people in Buon Ma Thuot now perform an increasingly simple agricultural ritual, Khan songs often sung during the growing ritual of agriculture increasingly sparse. The gongs to the Ede people is the voice that conveys the aspiration of the people to the gods so it is indispensable in such ceremonies as: ritual for the sylph; ritual for grassing; ritual for rice sowing; ritual for rice seed; ritual for paying for rain; ritual for the first rain. But now, the gongs are increasingly absent from the aforementioned ceremonies for various reasons, gradually replacing it with instruments of other ethnic groups. These things have made the holiness in the Ede's agricultural rituals more and more declining.

Agricultural rituals are an expression of the Ede's absolute belief in the gods, wishing the gods to bless agricultural cultivation. But today, the increasing level of science and technology applied in agriculture has made the Ede's dependence on the spirit of agricultural production significantly reduced, so the holiness in the practice of agricultural rituals decreases. During the ritual for the sylph, the traditional Ede people mainly used $\mathrm{kgal}^{1}{ }^{1}$ for cultivation, nowadays, they mainly use chainsaws to save effort and save time. In the past, when harvesting rice on milpas, the Ede people mainly harvest by hand and the means of transporting rice to storage is mainly a basket ${ }^{2}$, now the means of transport used by the Ede people are motorcycles, cars... The Ede people used to be completely passive in the wild, so they implemented the ritual for paying for rain whenever they needed water to irrigate their rice plants, but today, when they need water to irrigate, they often use motorized pumps to pump water from wells, ponds etc. to irrigate rice whenever they need it. The Ede people now regularly update the weather situation in agricultural cultivation through the weather forecast program in the media. Therefore, the ritual for paying for rain is rarely organized in the Ede villages, so the holiness of this ritual is greatly reduced.

Buon Ma Thuot now has a relatively fast economic development rate, so the life of Ede people here is greatly improved. The Ede's awareness level changed and their behavior towards agricultural rituals also changed, accordingly, the belief of the Ede people in the gods is declining. At present, there are rituals that have been eradicated very clearly such as ritual for rice seed; New rice eating ceremony, there are rituals that are completely lost like: ritual for grassing. One of the main reasons leading to the above situation is that the Ede people's perception of holiness in agricultural rituals is changing in a declining manner, so they must behave in accordance with the current situation. The fact that there are many Ede people in Buon Ma Thuot has abandoned the polytheism to other beliefs such as Protestantism, Christianity, etc. that also makes the belief of Ede people in the gods also

\footnotetext{
1 "Xà gạc": This is a steel blade inserted vertically into the hunchback of a curved handle made of solid bamboo. "Xà gạc" is used in manufacturing, fighting, building houses and also as a kitchen tool.

${ }^{2}$ Rice containers are made of bamboo and neohouzeaua, with high walls, wide and round mouth, and often have lids
} 
decrease. Besides, many Ede villages in Buon Ma Thuot now change their agricultural practices. They abandon rice cultivation and switch to industrial crops such as coffee and pepper. As a result, rituals associated with agricultural farming have been increasingly conducted. The corollary is that the holiness in agricultural rituals also decreases over time.

\subsection{Changes in content and form}

\section{* The life-cycle ritual}

The long traditional stilt house of the Ede people $s$ the main ritual practice space of the life-cycle ritual but now through the process of contact and cultural exchanges with other ethnic groups, the long stilt house in the Ede villages in Buon Ma Thuot is constructed by concrete and the traditional Ede architecture also fades away, instead of reinforced concrete houses designed in the style of other ethnic groups, no longer are the long stilt houses made entirely of natural wood as before. Therefore, the space for practicing life-cycle ritual of the Ede people in Buon Ma Thuot has changed dramatically. The rituals at birth have been simplified by the Ede people in Buon Ma Thuot and the abolition of many abstinence practices that they think is no longer suitable in the present era. Nowadays, Ede couples with infertile children often take each other to the hospitals to find the cause for treatment, they no longer perform the ritual of praying to the gods to pray for them to have children like before. Many Ede families in Buon Ma Thuot have now abandoned a few rituals in their life cycle rituals that they deem no longer suitable, in the remaining rituals, they often omit some steps in the practice of rituals in order to be more convenient and more suitable to today's life. Sacrifice offerings in the life-cycle ritual practice are also performed very flexibly by the Ede families today, for example, traditional offerings for the ritual for mother after giving birth is a pig, but today they change depending on the specific conditions of each family. The dishes offered to the gods during the practice of the Ede life cycle ritual are now richer in Buon Ma Thuot than before, in addition to traditional Ede food, they also add a lot of dishes of other ethnic groups, especially those of the Kinh ethnic group. Nowadays, when the contact and cultural exchange between the Ede people and other ethnic groups is growing, the participants in the life cycle ritual are also more diverse in ethnicity and age. For the traditional Ede people, when the girl came of age to fall in love with a certain boy, she would actively make acquaintance and bought gifts with her family to marry the boy to be her husband. But now in the marriage stage, the Ede boy is no longer passive as before, the rituals in the wedding ceremony today are usually agreed by the two previous families. So the steps to practice the ritual for offer today are greatly simplified, mostly formalistic.

The wedding ceremony of the Ede people in Buon Ma Thuot has also changed a lot, in addition to traditional instruments, they use more modern instruments of other ethnic groups. The Eden people's wedding space in Buon Ma Thuot is not always held in the village as it used to, nowadays, wedding space is often held in luxurious restaurants outside the village, the practice time of wedding ceremony today has been shortened and greatly simplified, it did not last for many days and nights like the traditional Ede wedding ceremony. During the wedding ceremony, in addition to traditional Ede songs, they use many other ethnic songs with different genres of music. Ritual for newly-weds' first visit to the briede's family of traditional Ede people used to take place 7 days after the wedding ceremony, now the number of days is much shorter, in some families, there are only 2 days or 3 days after the wedding. Gifts for the ritual for newly-weds' first visit to the briede's family also vary greatly depending on the specific conditions and circumstances of each family not following the rules of the previous Ede people. The form of residence after the wedding of Ede couples now has many changes, in particular, many Ede couples have increasingly tended to separate themselves into a small family rather than a form of extended family living in a traditional long house as before for many reasons.

Funeral in the traditional Ede family, the deceased's body is sometimes kept at home for 7 days before being taken to the burial ground, nowadays, they usually keep the dead body at home for only 3 days and send it to burial. Preparing for the funeral is also faster and more convenient than before, all offerings for the Ede people's funeral are usually available for purchase from funeral services, in particular, the coffin for the dead in the present era is mainly bought by the Ede people in Buon Ma Thuot, they no longer go to the forest to cut down trees to make coffins like before. Funeral vehicles of the Ede people now use modern means such as cars, motorcycles, ... but not rudimentary vehicles like before.

\section{* Agricultural ritual}

Offerings the Ede people worship the gods are the most valuable things for them to show their devotion to the gods. In the traditional agricultural ritual of the Ede people, corresponding to each different agricultural ceremony was a different animal of sacrifice and in the ritual for the first rain; ritual for rice watering and New rice eating ceremony, one of the offerings to the gods almost always must be "rượu cần"1. Currently, when their economic conditions are much better, the Ede people do only offered to the gods a cup of wine, but they also offer other expensive wines. Thus, when the value systems have changed, the sacrificial offerings of the Ede people have also

\footnotetext{
1 "Rượu cần" is a Vietnamese call for specialty wine brewed by the Ede people in jars, not distilled, when drinking, to use the need made of bamboo/perforated bamboo to drink. "Rượ cần" is a precious drink often used only in the sacrifices of the gods, festivals and entertaining guests.
} 
changed.

The Ede people think that the ritual meal is also a place to create conditions for all members of the family, in the village to increase intimacy and also the way people show their devotion to the gods, therefore, there is no shortage of meals, especially during agricultural rituals such as: the ritual for raining, ritual for the first rain; ritual for rice watering. Since ancient times, Ede's life has always been associated with mountain forests, Ede cuisine is a mixture of forest vegetables and foods completely taken from natural forest mountains. But now, in Buon Ma Thuot, with the fact that the area of natural forests is increasingly exhausted, the food source given by the Ede people is mainly bought from markets and supermarkets in Buon Ma Thuot.

The gong for the Ede people in the past was like the voice of the spirit, the soul, expressing joys and sorrows in production labor, therefore, the ritual for rice watering, new rice eating ceremony... indispensable for gongs. However now the gong is less and less in agricultural rituals such as the ritual for rice watering, new rice eating ceremony. In the past, when performing agricultural rituals, people often happily sang Ayray ${ }^{1}$ together. Upon departure, all guests were given a small package of food to the family, which implied a sharing of good fortune for everyone. The rest of the village would be told Khan by the elder or the respected people in the village, but now the Ede people's traditional games, dances and lyrics for agricultural rituals are fading away, instead of dancing to the music performed by modern instruments of other ethnic groups. In the current agricultural ritual of the Ede people, the content doesn't change as much as its appearance, the changes is in a simpler direction, as in ritual for the sylph and ritual for rice watering shows most clearly. Space for the agricultural ritual of the traditional Ede people has been done mainly on milpas, only a few rituals are performed right at the traditional long stilt house such as the ritual for rice seed, ritual for the first rain and new rice eating ceremony. The content and form of agricultural rituals performed by the Ede people in Buon Ma Thuot today are mainly based on the specific circumstances of each family, not necessarily following the tradition of Ede people.

\section{Conclusion}

The worshiping ceremony of the Ede people in Buon Ma Thuot is increasingly changing. Facing such changes, it is necessary to enhance the Ede people's awareness of the role and position of worship ritual in the development of each individual and in the development of social community is extremely necessary. In the current period, in order to preserve cultural identity values in the Ede people's worshiping rituals in Buon Ma Thuot, there should be specific groups of solutions such as: 1). Solutions for raising the Ede people's awareness of the role and importance of worship rituals in the cultural life of Ede clan. 2). The group of economic solutions to shorten the gap between the rich and the poor in the Ede community, creating conditions for the Ede people to integrate more and more quickly with the international economy which is taking place more and more strongly in Vietnam in general and in the Central Highlands in particular. 3). The group of political solutions to adjust policies on religion and beliefs is more and more suitable to the current situation in the Central Highlands in general and in Buon Ma Thuot in particular. 4). Group of cultural solutions to further enhance the training, fostering and updating of knowledge on ethnic, religious and belief culture for officials in charge of religion and belief in Buon Ma Thuot in particular and in the Central Highlands in general, is where many Ede people live.

But ultimately, in preserving and promoting the values in the worshiping ceremony of the Ede people in Buon Ma Thuot, the most important is the self-awareness of this ethnic community itself, because they themselves can understand what is right and what is no longer right for them in in modern times. From there, the Ede people themselves will be aware of the need to preserve and promote the values of worship rituals in particular and traditional ethnic culture in general.

\section{Bibliography}

1. A.A. Radugin (translator Vu Dinh Phong, 2002), Dictionary of Cultural Science, Institute of Literature and Art, Hanoi

2. Anne de hautec loque (2004), the Ede people - a matriarchal society, Ethnic Culture Publishing House, Hanoi.

3. Ngo Van Doanh (1995), Lễ hội bỏ mả bắc Tây Nguyên, National Culture Publishing House, Hanoi.

4. Be Van Dang (1983), Initially explaining cultural intercourse, Journal of Ethnography, No. 3.

5. E.B.Tylor (2001), Primitive Culture, National Culture Publishing House, Hanoi.

6. Nguyen Ton Nhan \& Phu Van Han (co-editor, 2013), Vietnamese dictionary, Southern Institute of Social Sciences, Polytechnic Dictionary Publishing House, Hanoi

7. Hoan Phe (chief editor, 2012), Vietnamese Dictionary, Institute of Linguistics, Polytechnic Dictionary Publishing House, Hanoi

8. Ngo Duc Thinh (2007), Cultural areas of the Central Highlands, Youth Publishing House, Ho Chi Minh City

9. Ngo Duc Thinh, Le Van Ky and Nguyen Quang Le (2007), Traditional customs of some ethnic minorities in the South Central Highlands, Hanoi Ethnic Publishing House.

\footnotetext{
${ }^{1}$ Khan is a genre of epic narration, traditional theater of heroes in the Central Highlands and other places, Ede people often call it Khan
} 
10. Ngo Duc Thinh (editor, 1992), Ede folklore, Ethnic culture publishing house, Hanoi.

11. Nguyen Huu Tham (2003), Khan Dam Hunt and Khan Dam Kteh Mlan, volume 1, National Political Publishing House, Hanoi.

12. Ho Chi Minh City University of Social Sciences and Humanities (2008), General Anthropology Curriculum, Ho Chi Minh City National Publishing House.

13. Provincial Party Committee - People's Council - People's Committee of Dak Lak Province (2015), Address of Dak Lak Province, Social Sciences Publishing House, Hanoi.

14. Nguyen Tuan Triet 2000), Historical development of Malay - Da Dao ethnic group, Social Science Publishing House, Hanoi.

15. Le Trung Vu (1995), Ede Folk Festival, Publishing House of Ethnic Culture, Hanoi. 